Apidologie, 1977, 8 (2), 155-168.

\title{
CONTROL OF THE WAX MOTH GALLERIA MELLONELLA ON BEECOMB BY H-SEROTPYE V BACILLUS THURINGIENSIS AND THE EFFECT OF CHEMICAL ADDITIVES
}

\author{
H. D. BURGES \\ Glasshouse Crops Research Institute, Littlehampton, West Sussex, \\ England
}

\section{SUMMARY}

Mature broodcombs were protected from attack by larvae of the wax moth Galleria mellonella (L.) for one year by impregnating $1 \%$ of dry fermentation solids containing spores and crystals of serotype $\mathrm{V}$ Bacillus thuringiensis into foundation beeswax. Protection rapidly declined in subsequent years. Of eleven additives tested in the hive, only $p$-aminosalicylic acid (PAS) increased potency, by a factor of approximately $\times 2$, but this effect did not last into the second year. Even with PAS, the method is uneconomic for practical control. In the hive trials, protection of comb varied greatly, due mainly to variation in the degree to which the bees had used the comb. Bees were unaffected.

Variation in potency against larvae was much less in laboratory assays made directly on sheets of foundation wax. Dipicolinic acid, penicillin, streptomycin, chloramphenicol, sulphadiazine, sulphapyridine, $\mathrm{MgSO}_{4}, \mathrm{NaNO}_{2}$ and a combination of $\mathrm{D}$ alanine, $\mathrm{D}$ valine and $\mathrm{D}$ serine reduced potency, while sulphamethizole, sulfisoxazole, EDTA, polymyxin, guanosine, mepacrine, oxine, enterovioform, nisin and $\mathrm{NH}_{3}$ benzoate had no significant effect. PAS again improved potency. In tests on the chemicals without bacteria, only chloramphenicol and $6.7 \%$ dipicolinic acid were slightly toxic to larvae.

Spores and delta endotoxin crystals of Bacillus thuringiensis Berliner, H-serotype $\mathrm{V}$ (B.t.V), prevent wax moth larvae damaging beecomb formed from treated beeswax foundation (Johansen, 1962; Burges and Bailey, 1968). Burges (1976b) found that the potency of B.t.V deteriorated before the bees used the foundation, an affect prevented by modifying the factory production and storage routine. These modifications led to improved control of the greater wax moth Galleria mellonella $\mathrm{L}$. for one year, but when four of 
the combs were used for bee colonies in beehives for a second year, control was reduced and varied widely. This indicates further deterioration of B.t. $\mathrm{V}$ in the hives, which can be curbed only by modifying or protecting B.t.V, since the bees and, to a lesser extent, local climate control conditions in the bee clusters.

The present paper describes trials of additives to prevent deterioration of B.t.V in the hive and an assessment of variability in practical control of G. mellonella by B.t.V.

Three types of additives were tried with the B.t.V. Germination inhibitors were included because it was thought that conditions in the hive might promote germination and consequent death of spores in the beecomb. Burges et al. (1976) concluded from a laboratory study of spores and crystals that a loss of potency in beehives is more likely to be due to death of spores than to deterioration of crystals. Antibiotics were added to kill or inhibit any microorganisms inhabiting the comb, or germinated B.t.V spores, which might produce proteinases that could attack the crystalline protein toxin. In the fermentation of certain B.t.V strains, proteinases are produced in certain conditions that destroy the activity of the crystals (H.T. DuLmage, personal communication). Proteinase inhibitors were included to protect the crystals against such enzymes or other naturally-occurring, proteinases in beeswax or honey.

\section{MATERIALS AND METHODS}

Insect breeding, assay methods and their precision are described in detail by Burges (1976a). Bacterial products, treated foundation beeswax and beecomb were stored at $2^{\circ} \mathrm{C}$ when not in hives. Insects were bred and assays incubated at $30^{\circ} \mathrm{C}$ and $70 \%$ R.H. Variations outside $\pm 0.3{ }^{\circ} \mathrm{C}$ and $\pm 5 \%$ R.H. were rare.

\section{Bacteria and chemicals}

B.t.V was used because this serotype is much more potent against G. mellonella than most others (Burges et al., 1967; Burges and BAILEY, 1968; Burges, 1975; Burges et al., 1976; Burges and JarretT, unpublished). All experiments except one were conducted with a normal production batch of liquid Thuricide, 90TS-8-25 (International Minerals and Chemical Corporation, Libertyville, Illinois, USA). A second batch, 90TS-63, was specially fermented for the other experiment after normal industrial production had been changed to another serotype.

The chemical additives are listed in table 1 and were analar grade, or the highest grade of purity available. 
WAX MOTH CONTROL BY $B$. Thuringiensis

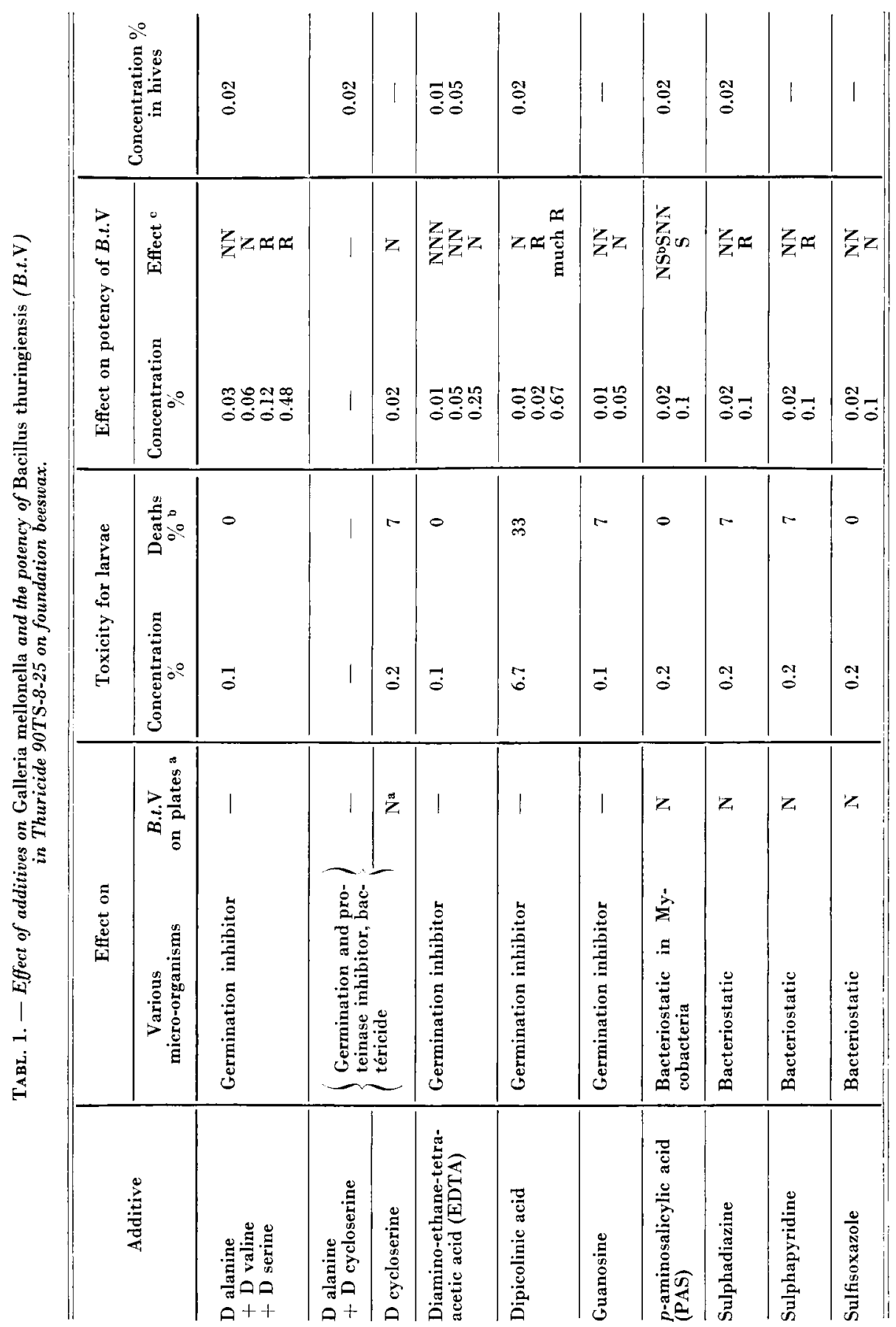




\begin{tabular}{|c|c|c|c|c|c|c|c|c|c|c|c|c|c|c|c|}
\hline \multicolumn{2}{|c|}{ 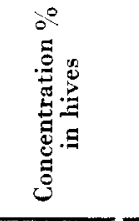 } & 1 & $\stackrel{\overbrace{}}{\varrho}$ & 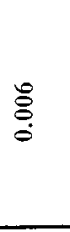 & $\mid$ & 1 & 1 & 1 & $\stackrel{8}{8}$ & 1 & 1 & | & 1 & & 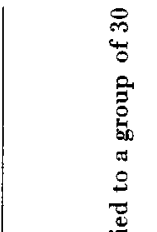 \\
\hline 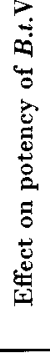 & 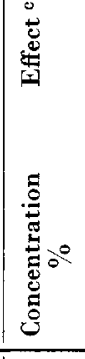 & 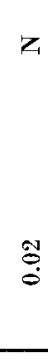 & . & 党里 & . & . & . & . & zzz & 学行 & . & . & . & 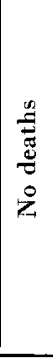 & 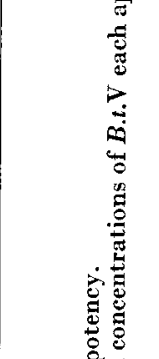 \\
\hline 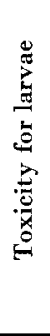 & 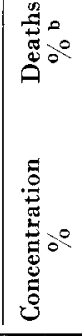 & $\stackrel{\sim}{\ominus}$ & $\stackrel{\overbrace{}}{\sigma}$ & $\stackrel{\mathscr{C}}{\circ}$ & $\ddot{\theta}$ & . & $\stackrel{\overbrace{}}{\varrho}$ & 1 & I & 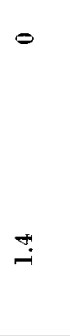 & $\stackrel{\leftrightarrow}{\text { ì }}$ & $\stackrel{9}{-}$ & $\stackrel{\leftrightarrow}{-}$ & . & $\begin{array}{l}1 \\
\end{array}$ \\
\hline 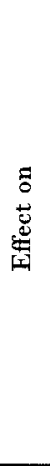 & 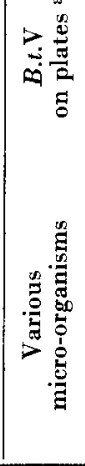 & 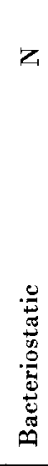 & 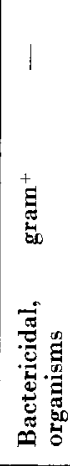 & 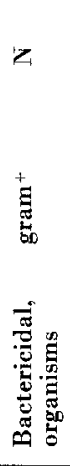 & 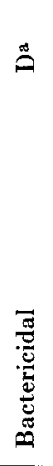 & 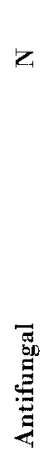 & 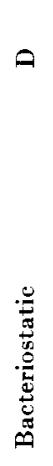 & 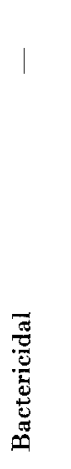 & 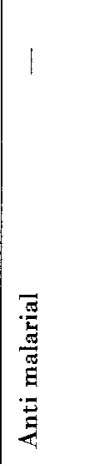 & 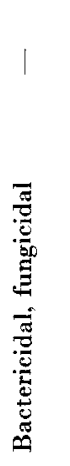 & 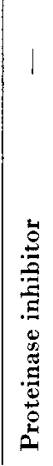 & 1 & 1 & 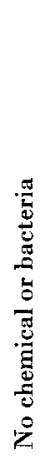 & 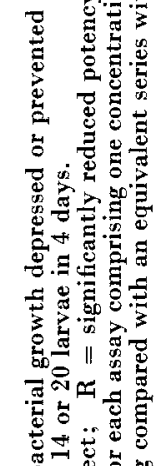 \\
\hline & 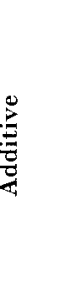 & 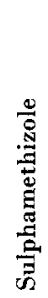 & 䓪 & 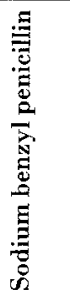 & 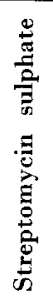 & 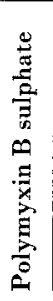 & 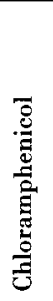 & 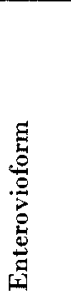 & 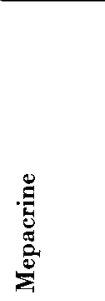 & .ֶ. & $\begin{array}{l}\delta^{*} \\
\mathbb{D}^{3} \\
\frac{5}{20}\end{array}$ & 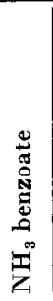 & 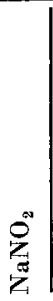 & 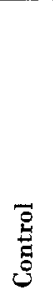 & 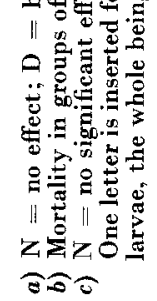 \\
\hline
\end{tabular}




\section{Assays with foundation beeswax}

Additives, also B.t.V with and without additives, were applied to foundation wax for initial laboratory assay against $G$. mellonella. To remove traces of the detergent or soapy mill lubricant which harm B.t.V (Burges, 1976b), the sheets of foundation were first washed overnight and dried. Aqueous chemical solutions and B.t.V suspensions were spread evenly over one side of sheets laid horizontally in a warm air tunnel. After drying, the other side was treated similarly. Sulphamethizole, which is insoluble in water, was dissolved in $10 \mathrm{ml}$ acetone and mixed with $990 \mathrm{ml}$ water. Oxine was first dissolved in absolute ethyl alcohol.

For each set of assays, larvae of uniform size were selected from a large batch, 14 days old, and allocated at random to groups, usually of 30 . Larvae from each group were confined singly in tubes on the foundation (Burges, 1976a). They were examined after 4 days and subsequently at 3-day intervals. Each set of assays included an untreated control group of larvae and, in experiments with B.t.V, five groups with serial concentrations of 90TS-8-25 without additives as a standard.

Test and standard LC50 values were calculated and compared by computer, using methods described by Finney (1952), Buiss (1952) and Burges (1976b).

\section{Hive trials}

For trials in bee colonies, B.t.V suspended in an aqueous solution of a chemical was spread over one side of a sheet of foundation and dried. This sheet was paired with an untreated sheet, treated side innermost and the pair were remilled, thus sandwiching the bacteria within the wax. The remilled sheet was trimmed to size, mounted in a wooden frame and placed in the brood section of a hive for one season. Sheets were treated at three concentrations of B.t.V with each chemical and at four concentrations without additives. Replicate sheets were placed in two apiaries, in which the resulting combs were kept longer in one than in the other.

For assay, sheets of about 130 G. mellonella eggs, judged visually by area, were placed on duplicate pieces of comb from each frame. Occasionally, hatching was poor and pieces were discarded if fewer than 25 larvae hatched - a number capable of severely damaging the comb. Two weeks after hatching, survivors were counted and, as an ancilliary observation to mortality, damage was assessed on an arbitrary scale. 


\section{RESULTS}

Toxicity of additives to G. mellonella larvae without bacteria

To test for direct toxicity to larvae, additives were applied to foundation beeswax at ten times the rate anticipated for use in hives. Only chloramphenicol and a very high rate of dipicolinic acid $(6.7 \%)$ were slightly toxic (> $7 \%$ mortality; table 1 ). One larva died with several of the additives $(=4$ or $7 \%$ mortality in table 1$)$, but although none of the control larvae died, this is not regarded as sufficient evidence for toxicity.

Effect of additives on the potency of $\mathrm{B}$. thuringiensis on foundation beeswax

The unreplicated assay on foundation can detect differences of about $\times 2.9$ in the potency of B.t.V (Burges 1976a). Increases in potency of this level or greater were obtained only with 0.02 to $0.1 \% p$-aminosalicylic acid (PAS), thesé improvements being statistically significant at the $5 \%$ level in half the assays when compared, in the same insect batch, with the standard bacterial series without additive (table 1). Low concentrations of dipicolinic acid, penicillin, streptomycin and chloramphenicol significantly depressed potency, as did much higher concentrations of sulphadiazine, sulphapyridine, $\mathrm{MgSO}_{4}, \mathrm{NaNO}_{2}$ and a combination of $\mathrm{D}$ alanine $+\mathrm{D}$ valine $+\mathrm{D}$ serine. With the exception of streptomycin, chloramphenicol, $\mathrm{MgSO}_{4}$ and $\mathrm{NaNO}_{2}$, which were tested at only one concentration, lower concentrations of these additives, and all the other additives, cause no significant change in potency.

\section{Effect of additives on the potency of $\mathrm{B}$. thuringiensis in hives}

Eleven of the additives were selected for hive trials at concentrations that did not impair the potency of $B$. thuringiensis on foundation beeswax in the laboratory (with the exception of dipicolinic acid which reduced potency at $0.02 \%$ after the decision to use it in hives had been made). No effects were noticed on the bee colonies.

There was wide variation in the " maturity " of different sheets of broodcomb, i.e. in the degree to which they had been used by the bees. A key to degrees of maturity is given in figs. 1 and 2. The least mature sheets had been formed into pale yellow cells on one side only, or the cells on both sides were pale yellow, short and unused for rearing bee larvae. The most mature comb was fully formed and dark brown, with cells lined by many layers of cocoons left by successive beebroods. Comb was, in general, less 
mature from the apiary in which it was held for the shorter time than from the other apiary.

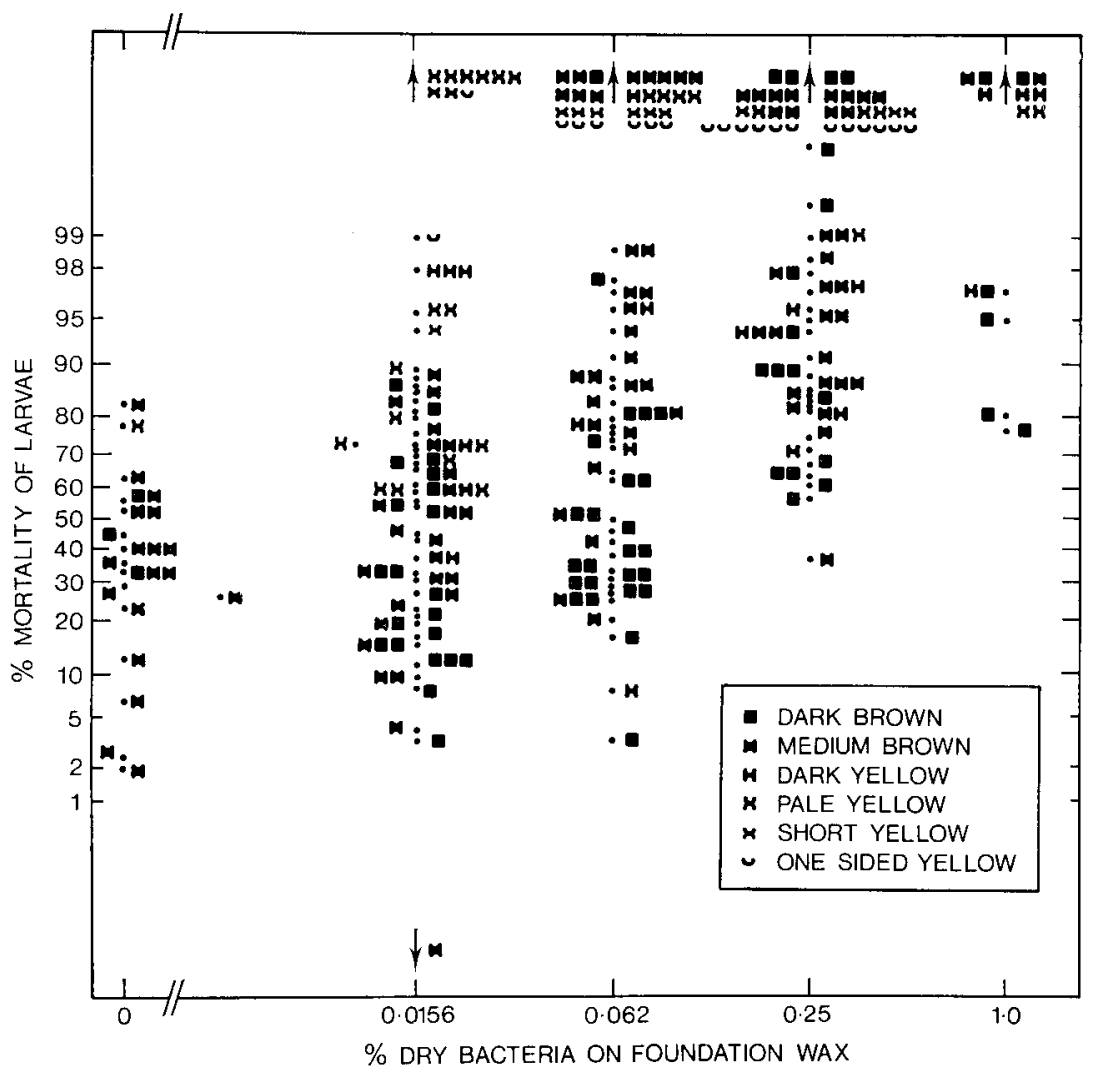

FIG. 1. - Mortality of Galleria mellonella larvae on broodcomb formed from foundation beeswax impregnated with Bacillus thuringiensis, serotype $V$.

Results for untreated control combs are shown on the left.

Mortality of $G$. mellonella larvae was least and damage greatest in the most mature combs, though with wide variation (figs. 1 and 2). On control combs without B.t.V, mortality also varied (fig. 1), with a mean of $39 \%$ on comb in all degrees of maturity and a mean of $37 \%$ on the two most mature categories of comb. The application of Abbott's correction for control mortality to the results of individual assays with bacteria and additives was unhelpful, but it was usefully applied to the combined results of replicate assays using the mean control mortality (table 2). The results of at least four replicate assays were combined for each additive. The combined results were recalculated including only the two most mature categories of comb, and these values were generally similar, but more useful, because the variances 
were lower. The LC50 for B.t.V with PAS was $\times 2.2$ more potent than that for B.t.V without additives (table 2). The difference was significant at the $10 \%$ level (' $t$ ' test). There was slightly less difference $(\times 1.9)$ between B.t.V with PAS and the combined results of $B . t . \mathrm{V}$ with all the other additives - significant at the $5 \%$ level, presumably because more assays were involved (table 2). The mean slope of the assays with B.t.V + PAS was comparatively steep (table 2) and so differences between LC values above the LC50 became progressively greater. None of the other additives caused significant effects.

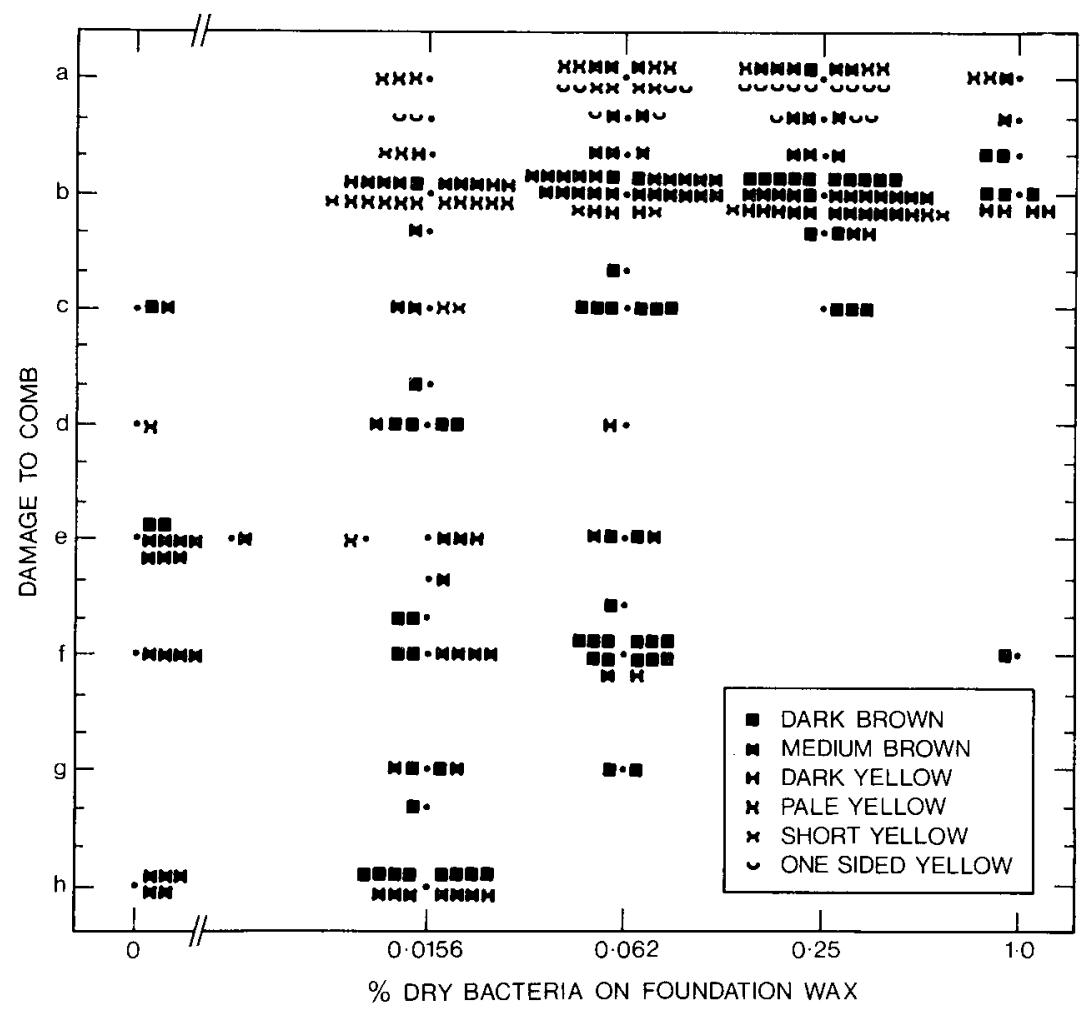

FIG. 2. - Damage caused by Galleria mellonella larvae to broodcomb formed from foundation beeswax impregnated with Bacillus thuringiensis, serotype $V$.

Results for untreated combs are shown on the left. The damage code is : $a=$ no damage; $b=$ less than $25 \%$ damaged cells; $\mathrm{c}=25$ to $49 \% ; \mathrm{d}=50$ to $74 \% ; \mathrm{e}=75$ to $99 \% ; \mathrm{f}=$ all damaged; $\mathrm{g}=\mathrm{only}$ rib of foundation left; $h \ldots$ no cells or wax left.

Effectiveness of the control of wax moth larvae on broodcomb by $\mathrm{B}$. thuringiensis

Only PAS had a recognisable, but small, effect on the potency of B.t.V. The mean LC50 values with and without the other chemical additives were very close, whether or not the two most mature categories of comb are considered 
alone (table 2), and so the effects of the additives can be ignored, so that the combined values provide extensive data about the protection of comb by B.t.V. The most important values are those for the two most mature categories of comb. The LC95 for these was $0.62 \%$ dry bacterial fermentation solids in foundation beeswax (95 \% fiducial limits, $0.38,1.37)$. The LC95 can be regarded as an adequate level of control, since the few surviving larvae present at the end of the 2-week exposure period would soon die. Similarly, using comb damage as the criterion, damage to less than $25 \%$ of the comb cells ( $a$ to $b$ in fig. 2; the damage to individual cells was usually light at this level) can be regarded as adequate control. On this basis 13 out of 16 records in figs. 1 and 2 show adequate control for one year in well-used comb treated at the $1 \%$ level of B.t.V. This is in reasonable accord with the calculated LC95 value.

TABL. 2. - Potency of Bacillus thuringiensis in Thuricide 90T5-8-25 in broodcomb after one season in beehives.

\begin{tabular}{l|c|c|c|c|c}
\multicolumn{1}{|c|}{$\begin{array}{l}\text { Presence of additives } \\
\text { Without }\end{array}$} & $\begin{array}{c}\text { Categories } \\
\text { of comb } \\
\text { maturity (a) }\end{array}$ & $\begin{array}{c}\text { No. of } \\
\text { larvae }\end{array}$ & $\begin{array}{c}\text { No. of } \\
\text { assays }\end{array}$ & $\begin{array}{c}\text { LC50 and } \\
\text { \% fiducial } \\
\text { limits }\end{array}$ & $\begin{array}{c}\text { Slope } \pm \\
\text { standard } \\
\text { error }\end{array}$ \\
\hline PAS & 2 maturest & 2954 & 7 & $0.081: 0.020,0.164$ & $1.34 \pm 0.11$ \\
With (b) & 2 maturest & 961 & 3 & $0.037: 0.027,0.046$ & $3.10 \pm 0.35$ \\
Without and with (b) & 2 maturest & 13306 & $39-49$ (c) & $0.069: 0.043,0.102$ & $1.90 \pm 0.06$ \\
Without & 2 maturest & 16260 & $46-56$ (c) & $0.071: 0.051,0.095$ & $1.75 \pm 0.06$ \\
With (b) & All & 5572 & 14 & $0.050: 0.027,0.077$ & $1.41 \pm 0.08$ \\
Without and with (b) & All & 17010 & $56-62$ (c) & $0.040: 0.034,0.047$ & $1.42 \pm 0.05$ \\
\hline
\end{tabular}

(a) See figs 1 and 2 for description of maturity categories.

(b) Excludings PAS.

(c) Range of numbers of pieces of comb involved at the three concentrations $0.0125,0.0625,0.25 \% \mathrm{dry}$ B.t.V in foundation, fewer pieces were involved at $1 \%$ (figs 1 and 2 ).

In the second year, only 8 out of 16 records showed good control with $1 \%$ B.t.V. In the same time, all of 12 records with $2 \%$ B.t.V showed good control, but only 3 out of 4 did so when kept for a third year. This indicates an important reduction in protection each year.

Some foundation was produced by using the second batch of Thuricide (90TS-63), undiluted, as the mill lubricant so that the pressure of the mill rollers forced B.t.V into the wax. A sensitive laboratory assay on an aliquot of this Thuricide, using an artificial food (Burges, 1976a), showed that its 
innate potency against G. mellonella larvae was high and similar to that of the 90TS-8-25 used in all other experiments (90TS-63, LC50 $=0.0034 \%$ wet bacterial concentrate, $W / W$, in the food for 7 days, $95 \%$ fiducial limits $=0.0024$ and $0.0049 \% ;$ 90TS-8-25, LC50 $=0.0052 \%$, limits $=0.0045$ and $0.0060 \%$ ). Assay of the foundation milled with 90TS-63 indicated that it had been impregnated with the equivalent of $0.85 \%$ 90TS-8-25 B.t.V, expressed as dry bacterial fermentation solids. This estimate was corroborated by the degree of control obtained in the hive. After one year, three sheets of pale yellow comb suffered no damage and killed all larvae in assays; two sheets of medium brown comb suffered less than $25 \%$ damaged cells and caused 95 and $96 \%$ mortality. The pale comb was used in hives for a second year, became medium brown, and on assay suffered less than $25 \%$ damaged cells and caused $97 \%$ larval mortality. Thus the calculated LC95 dosage $(0.62 \%)$ can be attained by the simple practical method of using undiluted Thuricide as mill lubricant, which requires almost no extra labour in the factory. The treated foundation must be dried and stored in dry conditions to avoid deterioration of B.t.V during warehouse storage (BURGES, 1976b).

In the comb assay, high larval mortality was usually correlated with light comb damage. In a few instances it was not. On a few pieces of comb, most larvae did not die until they were large, by which time they had caused severe damage. In fig. 1 , which illustrates only mortality, these particular high mortalities are not distinguished from the majority of high mortalities that occurred while larvae were young and the comb little damaged. Occasionally the opposite result was encountered : many larvae survived the 2 -week test period but were still small, having caused relatively little damage : such larvae would probably eventually die while still small. The particular few results are not distinguished in fig. 1 from the majority of high survivals with severe comb damage. In fig. 2 assessments of comb damage do not take into account differences in the initial numbers of larvae due to variable egg hatching. These imperfections were not important because damage followed the same trends as mortality in relation to dosage of B.t.V (figs. I and 2).

When forming combs, adult bees use a variable amount of new wax from their wax glands as well as the B.t.V-treated foundation wax. This affects the distribution of foundation wax in the comb. Variable distribution of foundation became evident as larvae ate the worst damaged combs, because the last part of the comb to be eaten was often a central rib of foundation, distinguishable by its paler colour. This variation in distribution doubtlessly contributed to the variation observed in larval mortality and damage to combs. Apart from this, larvae tunnelled and webbed the comb indiscriminately. Although Burges and BaILey (1968) did not detect a difference between outer and inner regions of broodcomb by bioassay with $G$. mellonella, ALI 
et al. (1973) claimed that only about $1 \%$ of their bacteria applied to foundation occurred in the cell walls of comb produced by a similar method. Although a tendency to eat cocoon material before wax in the cell walls was expected, no such tendency was observed in the present work.

\section{CONCLUSIONS AND DISCUSSION}

Great variation was encountered in the protection of the combs. A number of factors contributed to this variation. A basic factor is that mature combs without B.t.V varied in suitability as food for first instar G. mellonella larvae. Also, in treated combs, there was variation in the degree of dispersal of B.t.V-impregnated foundation wax in the cell walls. The main variation arose from differences in the maturity of combs, a variable greater than usual in the 1971 season. As the comb matures, the B.t. V are diluted by addition of wax by adult bees and by an accumulation of cocoon material from bee larvae (Simpson and Fairey, 1964), while at the same time the bacteria deteriorate. However, since such variation is a feature of conditions in which practical wax moth control must operate, it must be measured and the most susceptible larval stage, the first instar, should be used.

Effective measurements have been made in the presence of this variation by using large numbers of insects and assay replicates. Combination of assays of B.t.V without additives and those with all additives except PAS creates a large reliable body of data indicating that good protection of comb was obtained for one year by $1 \%$ of B.t.V in foundation wax. This concentration was conveniently impregnated into the foundation by using undiluted Thuricide as the mill lubricant. However, since protection declined in the second year and comb may be used in hives for up to 10 years, it is concluded that the method would be uneconomic in practice. Eventually the B.t.V is diluted by a factor of two to four by the addition of new wax and cocoon (Simpson and Fairey, 1964). Ignoring B.t.V deterioration and considering only the reduction of insect control by this dilution, a dilution by a factor of 1.5, for instance, between the first and second year would lower a first year LC95 to a second year LCo1, assuming a slope of 1.7 in the dosage-effect probit line (table 2). Although this is probably an under-estimate because the dilution is not symmetrical across the thickness of the comb, it suggests that deterioration of B.t.V may be the more important factor causing the steep drop in comb protection over the years. As a consequence of this drop, registration for efficacy has not been sought in Britain, although this use of Thuricide has been registered as safe (Ministrx of Agriculture, Fisheries and Food, 1968).

Ali et al. (1973) obtained comparable protection of comb against wax moth at a similar dosage of Thuricide HP. Neither ALI et al. (1973) nor 
Burges (in press) observed extensive leaching of spores from comb to honey. The falling potency of $B$. thuringiensis with the increasing age of comb might be renewed by dipping the comb into a Thuricide suspension. This would, however, greatly increase the number of spores picked up by the honey, and worker bees might lick off the bacterial deposit.

PAS, a vitamin analogue used mainly for the chemotherapy of tuberculosis, was the only additive to significantly increase the potency of B.t.V against wax moth larvae. In the tubercule bacillus, it is antagonised by the vitamin $p$-aminobenzoic acid (ToBIE and Jones, 1949), which is not essential for B.t. (Nrckerson and Bulla, 1974) nor usually essential for insects (House, 1974). At the higher concentrations used in the foundation wax assay, some of the antibiotics, sulphonamides and germination inhibitors impaired potency, presumably by inhibiting or killing the B.t.V spores. This agrees with the conclusion of BURGES et al. (1976) that, in G. mellonella, spores are more important than crystals in the pathogenicity of B.t.V.

Reçu pour publication en février 1977.

Eingegangen im Februar 1977.

\section{ACKNOWLEDGEMENTS}

I wish to thank Mr. R. Kelsall for experimental help, the International Minerals and Chemical Corporation, Libertyville, Illinois, USA for supplying B.t. V; also Robert Lee Ltd. for special milling of beeswax foundation and Dr. L. Bailey for arranging to have it exposed in hives.

\section{RESUMÉ}

LUTte CONTRE LA TEIgNe de LA CiRe, Galleria mellonella, A L'AIDE DU H-SEROTYPE V DE Bacillus thuringiensis ET INFLUENCES D'ADDITIFS CHIMIQUES

On a imprégné des feuilles de cire gaufrée de spores et de cristaux du sérotype $\mathrm{V}$ de Bacillus thuringiensis en incorporant du Thuricide dans l'eau qui lubrifie le gaufrier. On a inoculé en laboratoire à $30^{\circ} \mathrm{C}$ des cufs de la teigne de la cire, Galleria mellonella, aux rayons de couvain construits par les abeilles à partir de la cire gaufrée imprégnée. Les bactéries, présente à $1 \%$ dans le Thuricide (en poids sec dans la cire gaufrée) ont protégé pendant un an les rayons de l'attaque du papillon. Lorsqu'on a utilisé les années suivantes les rayons dans des ruches, la protection a rapidement baissé. Pour les essais avec les 11 additifs on a utilisé la méthode d'imprégnation suivante : sur un côté d'une feuille de cire gaufrée on faisait sécher en série des suspensions concentrées de bactéries renfermant un additif, puis on prenait une autre feuille de cire que l'on plaçait sur la surface traitée et l'on pressait les deux feuilles pour obtenir des feuilles imprégnées en leur milieu de bactéries et d'additif. Une analyse précise des résultats obtenus avec des rayons construits à partir de ces feuilles montre que seul l'acide p-aminosali- 
cylique (PAS) a aceru, d'environ 2 fois, le pouvoir protecteur, mais l'effet a disparu la seconde année. Même avec le PAS la méthode n'est pas rentable pour lutter contre la teigne de la cire sur le plan commercial. En tenant compte de l'ensemble des essais on a pu évaluer la variation de l'effet protecteur. Celle-ci était grande et dépendait essentiellement du degré auquel les abeilles avaient utilisé le rayon; plus l'utilisation du rayon était forte, plus l'effet protecteur baissait. Les traitements n'ont pas affecté les abeilles.

On a procédé en laboratoire à une mesure plus précise du pouvoir des bactéries associées aux additifs en plaçant à 30 "C, directement sur la cire gaufrée traitée sur ses 2 faces, des larves de Galleria âgées de 14 jours. Certaines concentrations d'acide dipicolinique, de pénicilline de streptomycine, de chloramphénicol, de sulfadiazine, de sulfapyridine, de $\mathrm{MgSO}_{4}$, de $\mathrm{NaNO}$, et d'une combinaison de $D$-alanine, $D$-valine et $D$-serine ont diminué le pouvoir protecteur, tandis que le sulfaméthizol, le sulfisoxazol, l'EDTA, la polymixine, la guanosine, la mépacrine, l'oxine, l'entéroviofrome, la nisine et le benzoate d'ammonium n'ont eu aucun effet significatif. Le PAS a là aussi accru le pouvoir protecteur. Lors des tests réalisés en laboratoire avec les additifs à des doses dix fois supérieures à celles utilisées dans les ruches, seuls le chloramphénicol et l'acide dipicolinique à $6,7 \%$ furent légèrement toxiques pour les larves.

\section{ZUSAMMENFASSUNG}

\section{BEKÄMPFUNG DER WACHSMOTTE Galleria mellonella $\mathbf{L}$. AUF DER BIENENWABE MIT Bacillus thuringiensis (SERUMTYPUS V) UND DIE WIRKUNG CHEMISChER ZUSÄTZE}

Bienenwachs zur Herstellung von Mittelwänden wurde mit Sporen und Kristallen des Serumtyps V von Bacillus thuringiensis imprägniert. Dazu wurde dem Lösemittel der Wabenpresse Thuricid zugesetzt. Die von den Bienen aus den imprägnierten Mittelwänden gebauten Brutwaben wurden sodann im Labor bei $30^{\circ} \mathrm{C}$ mit den Eiern von Galleria mellonella infiziert. Ein Prozent Bakterien im Thuricid (ausgedrückt als Trockengewicht in der Mittelwand) schützten ein Jahr lang die Waben vor Wachsmottenbefall. Wurden die Waben weitere Jahre benutzt, nahm die Schutzwirkung rasch ab. Bei Versuchen mit elf Zusätzen zu den Bakterien wurde die Imprägnierung auf folgende Weise durchgeführt : Eine Seite der mit der Bakteriensuspension und einem Zusatz besprühten Mittelwand liess man trocknen, dann wurde eine zweite Mittelwand auf die behandelte Mittelwandseite aufgelegt und beide zusammen noch einmal gepresst. So entstanden Mittelwände, bei denen Bakterien und Zusätze sich zwischen zwei fest aufeinander gepressten Schichten befanden. Genaue Analysen der Untersuchungsergebnisse der Waben, die auf diesen Mittelwänden gebaut worden waren, zeigten, dass nur p-Amino-salizylsäure (PAS) die Wirksamkeit erhöhte und zwar fast um das Doppelte. Doch die Wirksamkeit überdauerte ein zweites Jahr im Volk nicht. Aber auch mit dem Zusatz von PAS ist die Methode für die praktische, kommerzielle Wachsmottenbekämpfung nicht wirtschaftlich. Eine Überprüfung sämtlicher in Völkern durchgeführten Versuche ermöglichte es, die Veränderungen in der Schutzwirkung festzustellen. Sie waren gross und hauptsächlich durch die verschieden starke Benutzung der Waben durch die Bienen bedingt, wobei mit zunehmender Benutzung die Schutzwirkung nachliess. Die Bienen selbst wurden durch die Behandlung der Waben nicht gefährdet.

Eine genauere Messung der Wirksamkeit von Bakterien und Zusätzen wurde im Labor durchgeführt. 14 Tage alte Galleria-Maden wurden bei $30^{\circ} \mathrm{C}$ direkt auf beidseitig behandelte Mittelwände gebracht. Einige Konzentrationen von Dipicolinsäure, Penicillin, Streptomycin, Chloromycetin, Sulfadiazin, Sulfapyridin, $\mathrm{MgSO}_{4}, \mathrm{NaNO}_{2}$ und eine Kombination von D-Alanin 
D-Valin und D-Serin verringerten die Wirksamkeit, während Sulfamethizol, Sulfisoxazol, EDTA, Polymixin, Guanosin, Mepacrin, Oxin, Enterovioform, Nisin und benzoesaures $\mathrm{NH}_{3}$ ohne signifikanten Einfluss waren. PAS dagegen erhöhte die Wirksamkeit. Bei Laborversuchen, in denen das Wachs ohne Bakterien, jedoch mit Zusätzen in zehnfacher Stärke wie bei den Versuchen im Volk behandelt wurde, waren nur Chloromycetin und $6,7 \%$ ige Dipicolinsäure leicht giftig für die Galleria-Maden.

\section{REFERENCES}

Ali A. - U. - D. D., Andellatif M. A., Bakry N. M. and El-Sawaf S. K., 1973. - Studies on the biological control of the greater wax moth, Galleria mellonella II. Impregnation of comb foundation with Thuricide-HP as a method of control. J. apic. Res., 12, 125-130.

Burss C. I., 1952. - « The statistics of bioassay ». 183 p. Academic Press, New York.

Burges H. D., 1975. - Bacteria : Bacillus thuringiensis in moths. Rep. Glasshouse Crops Res. Inst. 1974, 99, 243-254.

Burges H. D., 1976a. - Techniques for the hioassay of Bacillus thuringiensis with Galleria mellonella. Ent. exp. and Appl., 19, 243-254.

Burges H. D., 1976b. - Persistence of Bacillus thuringiensis in foundation beeswax and in beecomb in beehives for the control of Galleria mellonella. J. Invertebr. Pathol., 28, 217-222.

BURGes H. D. and others, 1967. - The standardization of Bacillus thuringiensis : tests on three candidate reference materials. In : Insect Pathology and Microbial Control (P.A. van der Laan, ed.), North-Holland Publishing Co., Amsterdam, 314-337.

Burges H. D. and Bailey L., 1968. - Control of the greater and lesser wax moths (Galleria mellonella and Achroia grisella) with Bacillus thuringiensis. J. Invertebr. Pathol., 11, 184195.

Burges H. D., Thomson E. M. and Latchford R. A., 1976. - Importance of spores and לे-endotoxin protein erystals of Bacillus thuringiensis in Galleria mellonella. J. Invertebr. Pathol., 27, 87-94.

Finney D. J., 1952. - Probit analysis, 2nd ed., 318 pp. Cambridge University Press, Cambridge.

House H.L., 1974. - Nutrition. In : The Physiology of Insecta (M. Rockstein, ed.), vol 5, Academic Press, New York, 1-62.

IgNOFFo C. M., 1963. - Sensitivity spectrum of Bacillus thuringiensis var : thuringiensis Berliner to antibiotics, sulfonamides and other substances. J. insect. Pathol., 5, 395-397.

Johansen C. I., 1962. - Impregnated foundation for waxmoth control. Glean. Bee Cult., 90, $682-684$.

Ministry of Agriculture, Fisheries and Food., 1968. - Chemical compounds used in agriculture and food storage. Recommendations for safe use in Great Britain. Bacillus thuringiensis Berliner. - Recs/338. Jan. 1, 1968. Presticides Branch, Horseferry Rd., London, 1 p.

Nickerson K. W. and Bulla L. A. Jnr., 1974. - Physiology of sporeforming bacteria associated with insects : minimal nutritional requirements for growth, sporulation and paracrystal formation of Bacillus thuringiensis., Appl. Microbiol., 28, 124-128.

Simpson J. ANd Fairey E. M., 1964. - How efficiently can wax be extracted from old brood combs by simple methods? Bee World, 45, 99-103.

Tobie W. C. And Jones M. J., 1949. - Para-aminosalicylic acid in the metabolism of bacteria. J. Bacteriol., 57, 573. 